\title{
Isolation and selection of Bacillus strains with high potential probiotic that used in catfish farming (Pangasianodon hypophthalmus)
}

\author{
Nguyen Van Minh ${ }^{1 *}$, Nguyen Hoang Tuan Duy ${ }^{1}$, Do Phuong Quynh ${ }^{1}$, Tran Thi A Ni ${ }^{2}$, Tran \\ Kien Duc ${ }^{3}$, Duong Nhat Linh ${ }^{1}$ \\ ${ }^{1}$ Faculty of Biotechnology, Ho Chi Minh City Open University, Vietnam \\ ${ }^{2}$ MIDOLI Co., ltd, Vietnam \\ ${ }^{3}$ Ho Chi Minh City University of Science, Vietnam \\ *Corresponding author: minh.nv@ou.edu.vn
}

\begin{tabular}{|c|c|}
\hline ARTICLE INFO & ABSTRACT \\
\hline $\begin{array}{l}\text { DOI:10.46223/HCMCOUJS. } \\
\text { tech.en.10.1.355.2020 }\end{array}$ & $\begin{array}{l}\text { In this study, we isolated } 28 \text { strains of Bacillus spp. from } \\
\text { water samples, catfish pond mud samples and earthworm manure } \\
\text { (Perionyx excavates). By the cross-streak agar methods, } 22 \\
\text { Bacillus strains showed the inhibition ability to Edwardsiella } \\
\text { ictaluri, which caused Bacillary Necrosis Pangasius (BNP) in } \\
\text { catfish (Pangasianodon hypophthalmus). Both Bacillus sp. Q } 16 \\
\text { and } Q_{111} \text { strains showed the highest inhibition to E. ictaluri by the }\end{array}$ \\
\hline Received: August $19^{\text {th }}, 2019$ & double-layer agar methods. Finally, two Bacillus strains (Q16, \\
\hline Revised: December 27, 2019 & $\left.\mathrm{Q}_{111}\right)$ were selected as a source of potential probiotic because of \\
\hline Accepted: December 31 ${ }^{\text {st }}, 2019$ & $\begin{array}{l}\text { the ability of extracellular enzyme secretion (protease, amylase, } \\
\text { cellulose) strong growth at } 0,1-1 \% \text { salt concentrations, survival } \\
\text { within the pH range } 6-8 \text {, resistance to low } \mathrm{pH} \text { and low bile salts, } \\
\text { inability to produce haemolysin enzyme, sensitivity to eight } \\
\text { antibiotics in the three impacting groups (inhibition of wall } \\
\text { synthesis, inhibition mechanism of protein synthesis, inhibition of }\end{array}$ \\
\hline Keywords: & $\begin{array}{l}\text { nucleic acid synthesis). Two Bacillus strains }\left(\mathrm{Q}_{16}, \mathrm{Q}_{111}\right) \text { were } \\
\text { identified that they belong to Bacillus subtilis by biochemical }\end{array}$ \\
\hline $\begin{array}{l}\text { Bacillus subtilis, probiotic, } \\
\text { Edwardsiella ictaluri, } \\
\text { Perionyx excavatus, } \\
\text { Pangasianodon } \\
\text { hypophthalmus }\end{array}$ & $\begin{array}{l}\text { method and } 16 \mathrm{~S} \text { rRNA gene sequencing method. This study } \\
\text { indicated that two Bacillus strains }\left(\mathrm{Q}_{16}, \mathrm{Q}_{111}\right) \text { isolated from catfish } \\
\text { pond can be applied as high potential probiotics that used to farm } \\
\text { catfish. }\end{array}$ \\
\hline
\end{tabular}

\section{Introduction}

In recent years, the Catfish job (Pangasianodon hypophthalmus) at Mekong Delta is more developed and yield is being enhanced. However, the farmers carry out intensive farming constantly to increase yield and profit, therefore, the problem of catfish disease occurs more often and more damages. One of the common diseases in catfish, bacterial disease is the most effective in catfish farming, especially purulent kidney liver disease caused by Edwardsiella 
ictaluri (Dang \& Nguyen, 2012). Although the chemicals and antibiotics cure and protect catfish, the disadvantages of them increase antibiotic-resistance bacteria and decrease the effects of antibiotics on humans and animals (Moriarty, 1997). One of the solutions to this problem is using biological products in biological control disease (Sudha, Chauhan, Dixit, Babu, \& Jamil, 2010). Many pieces of research showed Bacillus have probiotic activity and biological control (Chao et al., 2012; Moriarty, 2006) in aquaculture. Gram-positive bacteria are used worldwide as probiotics. The wide applications belong to endospore-forming members of Bacillus genera (Huynh, Le, \& Cutting, 2005), in which Bacillus subtilis is commonly used in aquaculture. Probiotics have been shown resistance to diseases, and they are excellent preventive tools against pathogens. Probiotics play an important role in creating resistance to infectious diseases and in producing antibacterial materials that prevent pathogenic bacteria from getting into organisms. Some products demonstrated the ability of probiotics in the protection for aquatic animals against pathogenic infection such as Bacillus spp. against Strep. iniae (Cha, Rahimnejad, Yang, Kim, \& Lee, 2013). Probiotics have proven their effectiveness in improving water quality. They also enhanced the decomposition of organic matter, reduced nitrogen and phosphorus concentrations, and controlled ammonia, nitrite, and hydrogen sulfide (Cha et al., 2013; Ma, Cho, \& Oh, 2009). Nguyen et al. (2013) reported that isolated bacteria from earthworms have the potential to make probiotic products and biological control some bacteria's diseases on the aquatic animals. In this study, some Bacillus spp. strains were isolated and selected from catfish gut, water, muddy water pond samples and from earthworm manure (P. excavates), they are potential to make the probiotic products that could be applied to catfish farming.

\section{Materials and methods}

\subsection{Materials}

Bacillus spp. strains (Labeled as Q) were isolated from water, catfish muddy water pond and gut samples in Thoai Son district, An Giang province and Lap Vo district, Dong Thap province. Bacillus spp. strains (Labeled as $\mathrm{F}$ ) were isolated from earthworm manure ( $\mathrm{P}$. excavates), which were provided by Microbiology Lab at Ho Chi Minh City Open University. E.ictaluri was provided by Research Institute for Aquaculture No.2. Catfish were provided by hatchery Binh Thanh 1 of An Giang Fishers Association center.

\subsection{Methods}

\subsubsection{Isolation Bacillus spp.}

Bacillus spp. were isolated and purified on Nutrient Agar media (NA). Each strain was presumptive identification based on the Bergey method. The criteria of Bacillus spp. identification were positive bacteria, spore, positive Oxidase and positive catalase based on Bergey (1994, as cited in Holt, Krieg, Sneath, Staley, \& Williams, 1994).

\subsubsection{Antagonistic test to E. ictalurid}

Each Bacillus spp. strain was tested the ability to resist to E.ictaluri by Cross-Streak method. (Lemos, Toranzo, \& Barja, 1985). Double-layer agar method base on (Jock, Völksch, Mansvelt, \& Geider, 2002). The result was recorded in 24, 48 and 72h and repeated 3 times. 


\subsubsection{Production extracellular enzyme test}

This experiment was tested on some extracellular enzymes such as protease (caseinase, gelatinase), amylase, lipase, cellulase. Qualitative protease enzyme based on Montville (1983) (Montville, 1983), amylase and lipase enzymes based on Hankin and Anagnostakis (1975) (Hankin \& Anagnostakis, 1975), cellulase enzyme based on Samanta, Pal, and Sem (1989) (Samanta et al., 1989).

\subsubsection{Resistance saline and $\mathrm{pH}$ test}

Bacteria trial was cultured on TSB media (Tryptic Soy Broth) in $30^{\circ} \mathrm{C} / 24 \mathrm{~h}$, dilution with $\mathrm{NaCl} 0,85 \%$ at $10^{8} \mathrm{CFU} / \mathrm{mL}$ concentration based on McFarland 0.5 . In resistance saline test, $1 \%$ bacteria broth was cultured on TSB media with different $\mathrm{NaCl}$ concentrations: 0,$1 ; 0,2 ; 0,4$; 0,$6 ; 0,8$ and $1 \%(\mathrm{w} / \mathrm{w})$, in $30^{\circ} \mathrm{C} / 24 \mathrm{~h}$. In the resistance $\mathrm{pH}$ test, the range of $\mathrm{pH}$ was examined from 4 to 10 . Bacteria could tolerance saline and $\mathrm{pH}$ when could growth in media.

\subsubsection{Resistance to acid gastric test}

Bacteria trial were cultured on DSM media (Difco Sporulation Medium) $37^{\circ} \mathrm{C} / 48 \mathrm{~h}$. The bacteria broth at $10^{8} \mathrm{CFU} / \mathrm{mL}$ concentration, $0,1 \mathrm{~mL}$ bacteria broth was transferred into $10 \mathrm{~mL}$ TSB media (Tryptic Soy Broth) at $\mathrm{pH}=2, \mathrm{pH}=3$ in shake cultured in $30^{\circ} \mathrm{C}, 200 \mathrm{rpm} / \mathrm{min}$. At $0 \mathrm{~h}, 1 \mathrm{~h}, 2 \mathrm{~h}, 1 \mathrm{~mL}$ broth was certificated cold $6000 \mathrm{rpm} / 5 \mathrm{mins}$, kept and washed sediment by $\mathrm{NaCl} 0,85 \%$ and dilution to appropriate concentration in $\mathrm{NaCl} 0,85 \%$. The sample was cultured on TSA media (Tryptic Soy Agar) in 3 different consecutive concentrations, in $37^{\circ} \mathrm{C} / 24-48 \mathrm{~h}$. Count and analyze the living bacteria trial follow the formula: \% living bacteria: $\mathrm{Ni} / \mathrm{Nx} \times 100$, $\mathrm{Ni}=\log \mathrm{CFU} / \mathrm{mL}$ after culture time, $\mathrm{Nx}=\log \mathrm{CFU} / \mathrm{mL}$ at $0 \mathrm{~h}$ (Cukrowska et al., 2009).

\subsubsection{Resistance to bile salt test}

Bacteria broth was prepared at $10^{8} \mathrm{CFU} / \mathrm{mL}$ concentration. $0,1 \mathrm{~mL}$ bacteria broth was transferred into $10 \mathrm{~mL}$ TSB media with bile salt in $0,5,1$ and $2 \%$ concentration, shake culture in $37^{\circ} \mathrm{C}, 200 \mathrm{rpm} / \mathrm{min}$. At $0 \mathrm{~h}, 1 \mathrm{~h}, 2 \mathrm{~h}, 1 \mathrm{~mL}$ broth sample was removed and analyze living bacteria.

\subsubsection{Production hemolysin enzyme test}

Isolated bacteria were cultured on BA (Blood Agar), this media was added 5\% sheep blood, in $30^{\circ} \mathrm{C} / 24$. This experiment was conducted with control (non-hemolysin) (Van, 2006).

\subsubsection{Minimum Inhibitory Concentration (MIC)}

The antibiotic was dilution in MHB (Mueller Hinton Broth). Each bacterium was isolated \& cultured on $\mathrm{MHB}$ in $37^{\circ} \mathrm{C} / 24 \mathrm{~h}$ and diluted in $\mathrm{NaCl} 0,85 \%$ at the final concentration is $10^{6} \mathrm{CFU} / \mathrm{mL}$. The antibiotic was diluted in 2 consecutive concentration in MHB media with line concentration: $128 ; 64 ; 32 ; 16 ; 8 ; 4 ; 2 ; 1 ; 0,5 ; 0,25 ; 0,125 ; 0,0625$, transferred into each tube $0,5 \mathrm{~mL}$ antibiotic and $0,5 \mathrm{~mL}$ bacteria brotha at $10^{6} \mathrm{CFU} / \mathrm{mL}$, in $37^{0} \mathrm{C} / 16-18 \mathrm{~h}$. The control sample was conducted without antibiotics. The result was based on MIC Breakspoint for Bacillus genus, according to CLSI (Schwalbe, Steele, \& Goodwin, 2007).

\subsubsection{Identification}

Selection bacteria were identified by the biochemical method Bergey (as cited in Holt, Krieg, Sneath, Staley, \& Williams, 1994) and the molecular method based on 16S rRNA was conducted by Macrogen Company, Korea. 


\section{Results}

\subsection{Isolation of Bacillus spp.}

We isolated 6 Bacillus spp. from earthworm manure (P. excavates) (Labeled as F) and 22 Bacillus spp. from water, catfish pond mud and gut (Labeled as Q). Its characteristics are Gram-positive, catalase-positive, rod-shaped, intracellular spore.
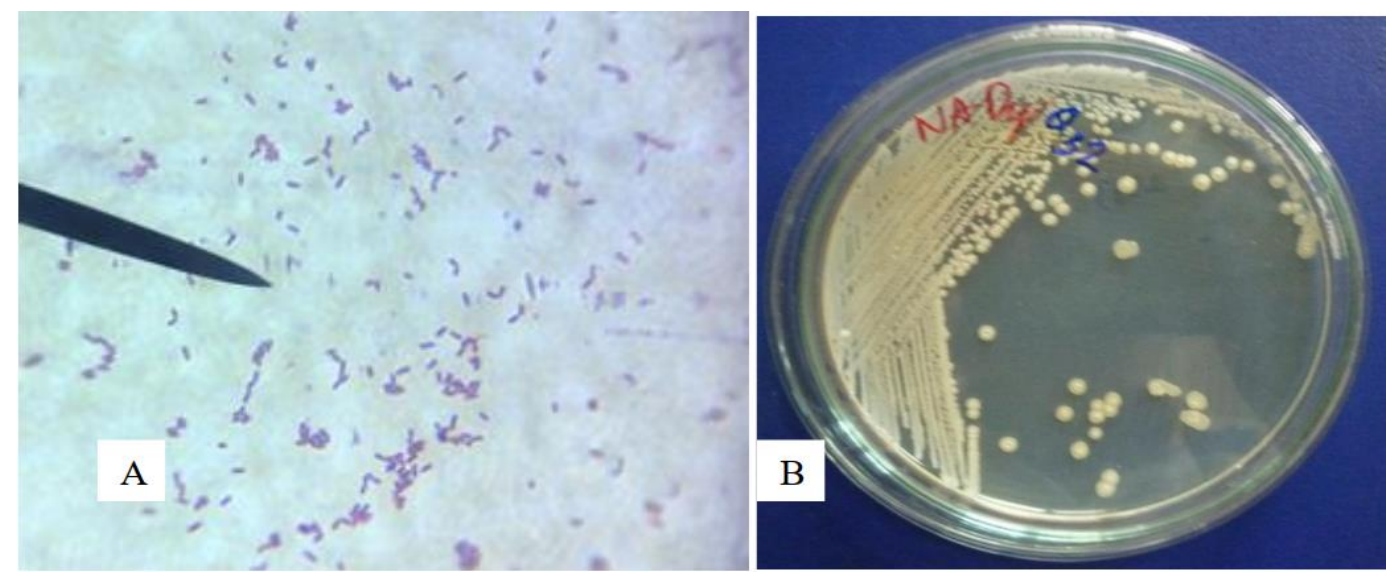

Figure 1. (A) Gram-stained image of Bacillus Q32. (B) Bacillus Q32 colony characteristics on NA after 24 hours of culture

\subsection{The result of antagonistic}

There are 22 Bacillus spp. Strain $\left(F_{11}, F_{2}, F_{27}, F_{33}, Q_{11}, Q_{111}, Q_{12}, Q_{13}, Q_{16}, Q_{162}, Q_{21}\right.$, $\left.\mathrm{Q}_{23}, \mathrm{Q}_{25}, \mathrm{Q}_{240}, \mathrm{Q}_{270}, \mathrm{Q}_{0}, \mathrm{Q}_{29}, \mathrm{Q}_{3}, \mathrm{Q}_{30}, \mathrm{Q}_{32}, \mathrm{Q}_{2}, \mathrm{Q}_{6}\right)$ that could resist to E. ictaluri at 24h, 48h, and $72 \mathrm{~h}$ from 28 strain were tested by the cross-streak method and the double-layer agar method. The results were shown in Figure 2 and Figure 1. 2 strains Bacillus sp. Q16 and Q 111 showed the highest resistance to E. ictaluri with the inhibition zone over $30 \mathrm{~mm}$. According to the research of Ho et al. (2017) showed the B. pumilus (47B), B. amyloliquefaciens (48C, 51G, 39B) and B. megaterium (4A, 62D) showed high inhibition activity against E. ictaluri, with inhibition zone over $10 \mathrm{~mm}$. Therefore, Bacillus sp. $\mathrm{Q}_{16}$ and $\mathrm{Q}_{111}$ strains were selected for the next experiment.

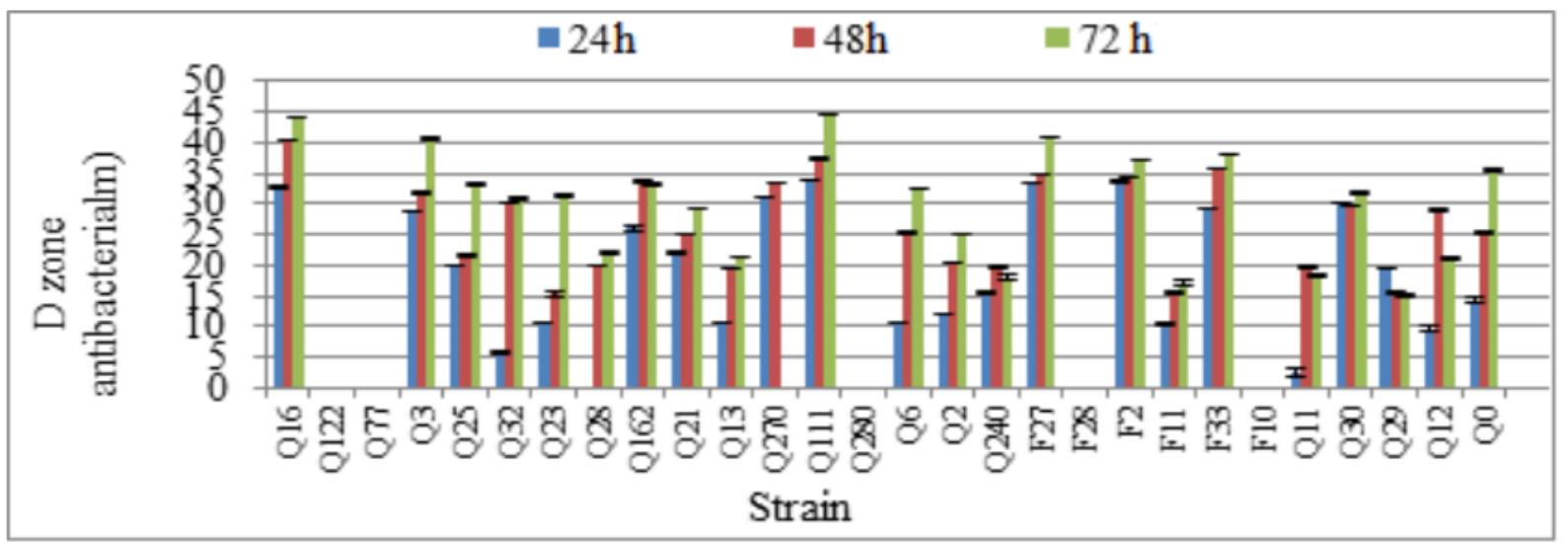

Figure 2. Bacillus strains resistance E.ictaluri at 24h, 48h, and $72 \mathrm{~h}$ 

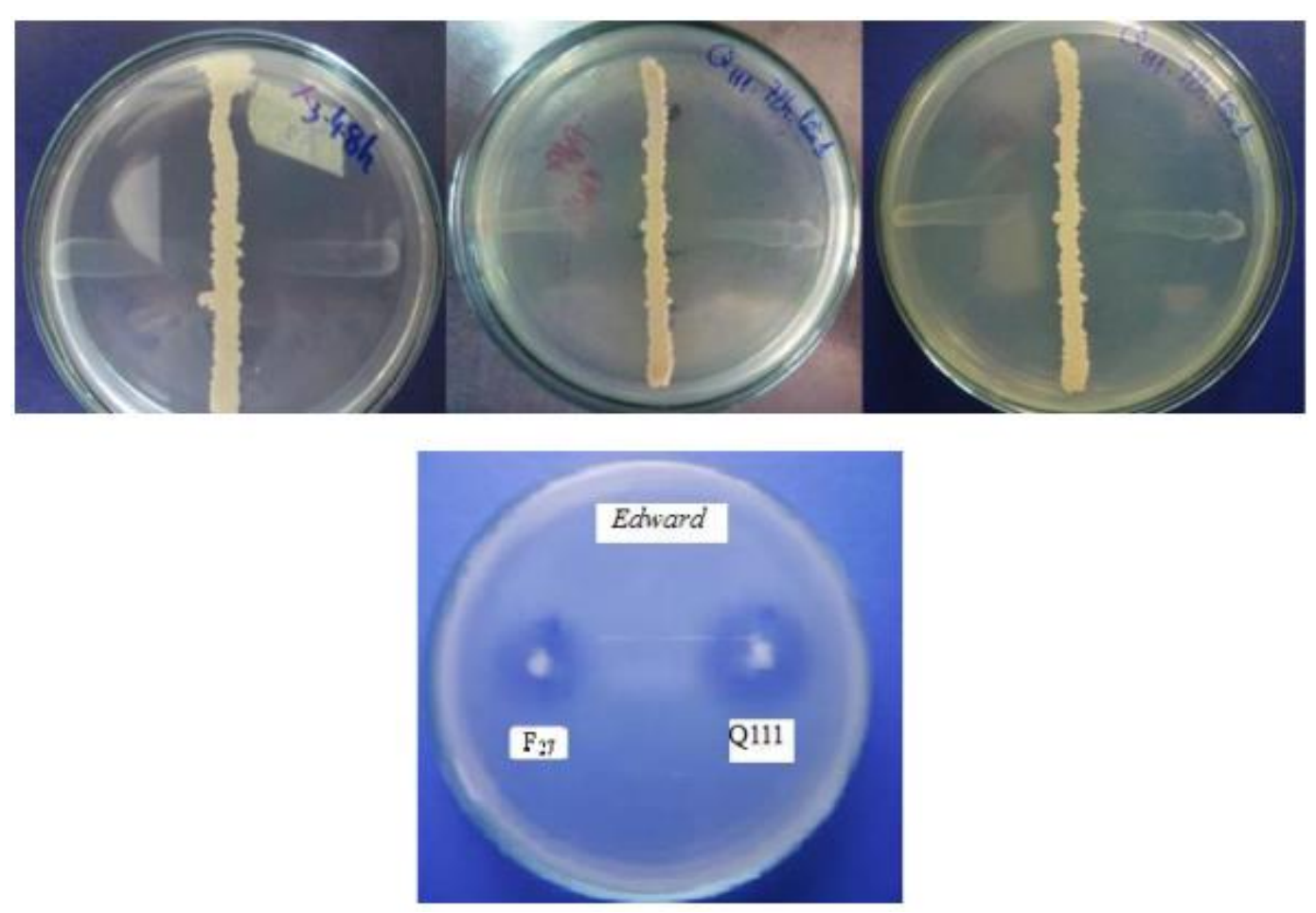

Figure 3. Bacillus strains resistance E.ictaluri

\subsection{Production extracellular enzyme test}

The result showed Bacillus sp. $\mathrm{Q}_{16}$ and $\mathrm{Q}_{111}$ could produce extracellular enzymes such as amylase enzyme, gelatinase, caseinase, cellulase and couldn't produce lipase enzyme (Figure 4). In addition, enzyme production activity of Bacillus was also Joo, Hur, Han, and Kim (2007), showed that strains of Bacillus spp. can produce many extracellular enzymes such as amylase, cellulase, lipase. 

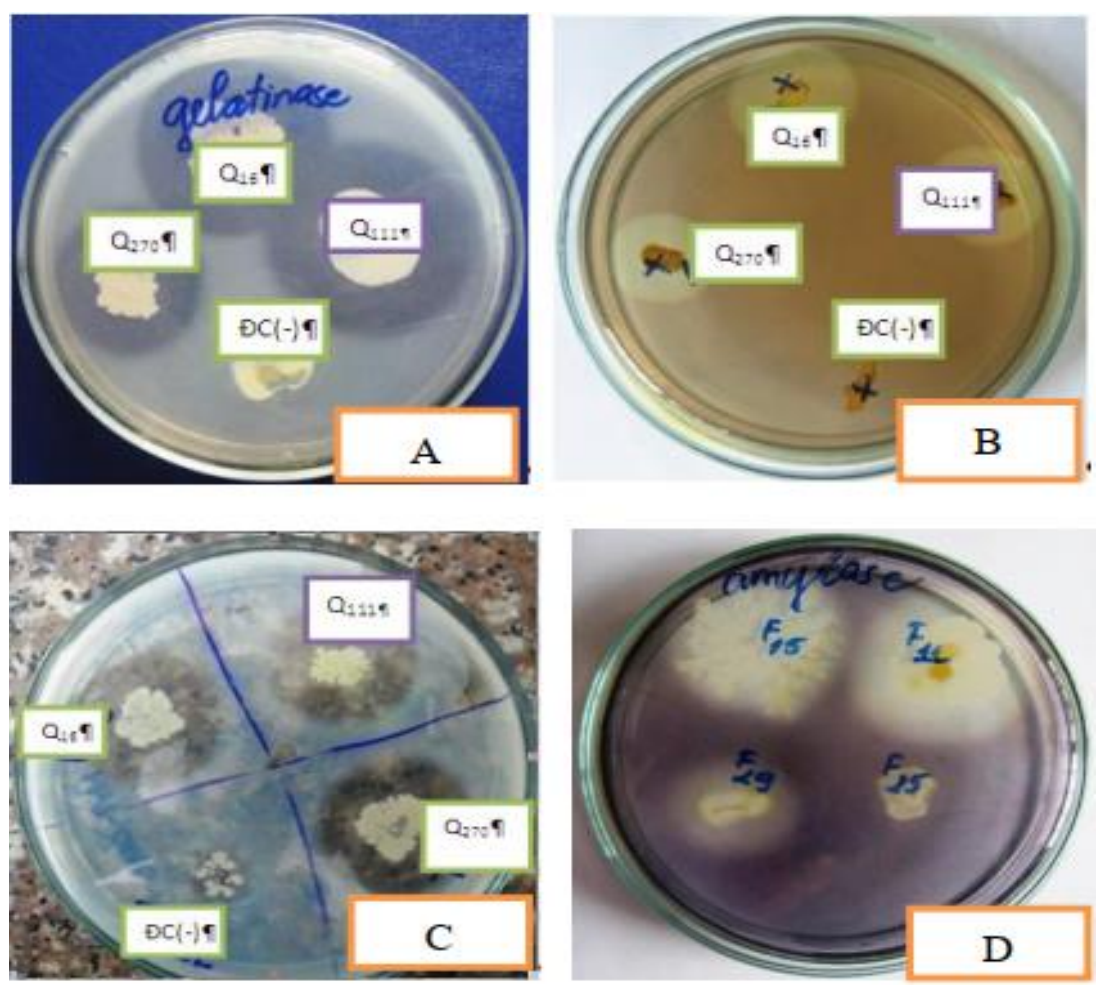

Figure 4. Extracellular enzyme production test (A: Gelatinase, B: Cellulase, C: Caseinase, D: Amylase)

\subsection{Resistance to saline and pH test}

Bacillus sp. $\mathrm{Q}_{111}$ and $\mathrm{Q}_{16}$ could resistance and strong growth in concentration saline to $1 \%$. In the $\mathrm{pH}$ test, 2 strains could strong growth in $\mathrm{pH}$ from 6 to 8 . Ho et al. (2017) showed Bacillus could growth in $\mathrm{pH}$ from 5 to 10 .

\subsection{Resistance to acid gastric test}

The result of Bacillus sp. Q16 and $\mathrm{Q}_{111}$ was shown in Figure 5, Figure 6 and Figure 7.

In $\mathrm{pH}=3$ and 2, Bacillus sp. $\mathrm{Q}_{111}$ và $\mathrm{Q}_{16}$ could strong growth in $2 \mathrm{~h}$. Therefore, 2 strains could resistance to acid gastric. This result was similar to the research of Sudha et al. (2010) and Hyronimus, Marrec, Sassi, and Deschamps (2000) showed that Bacillus spp. could live in $\mathrm{pH}=2,3$. 


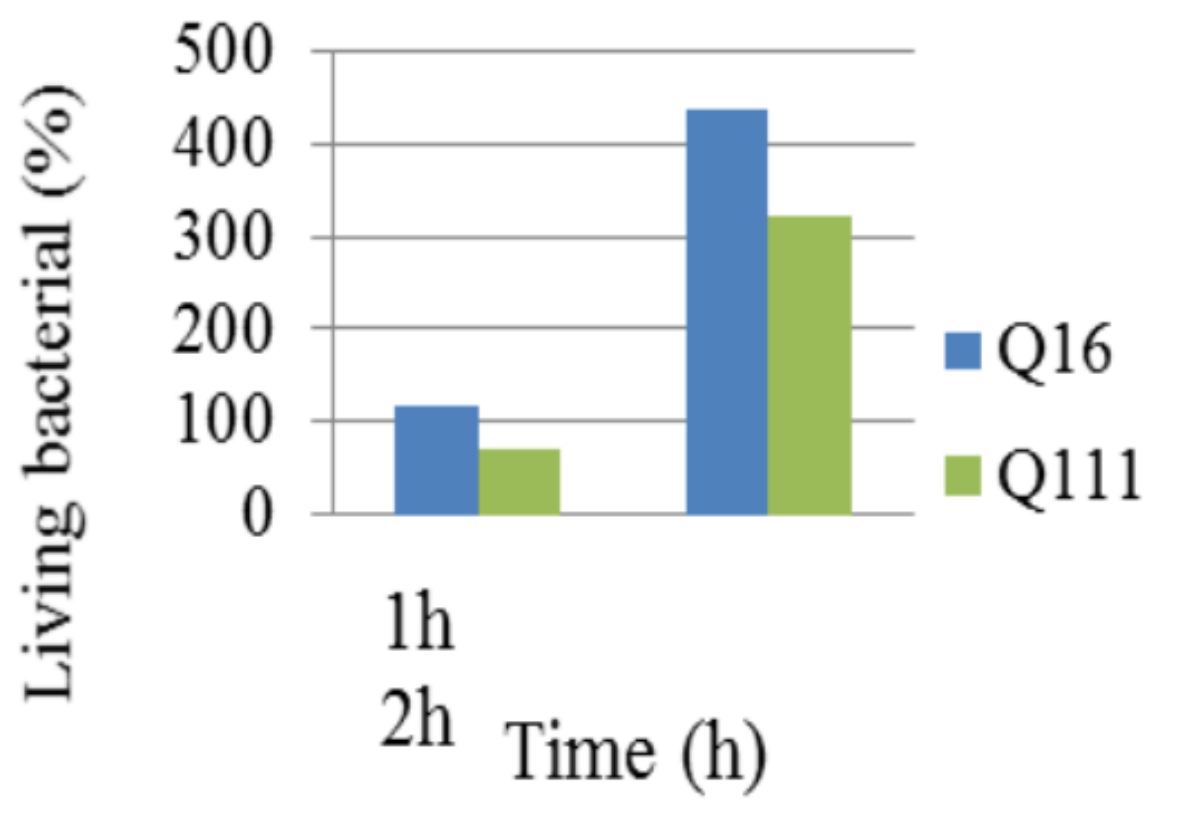

Figure 5. Living bacterial of strains test with $\mathrm{pH}=2$

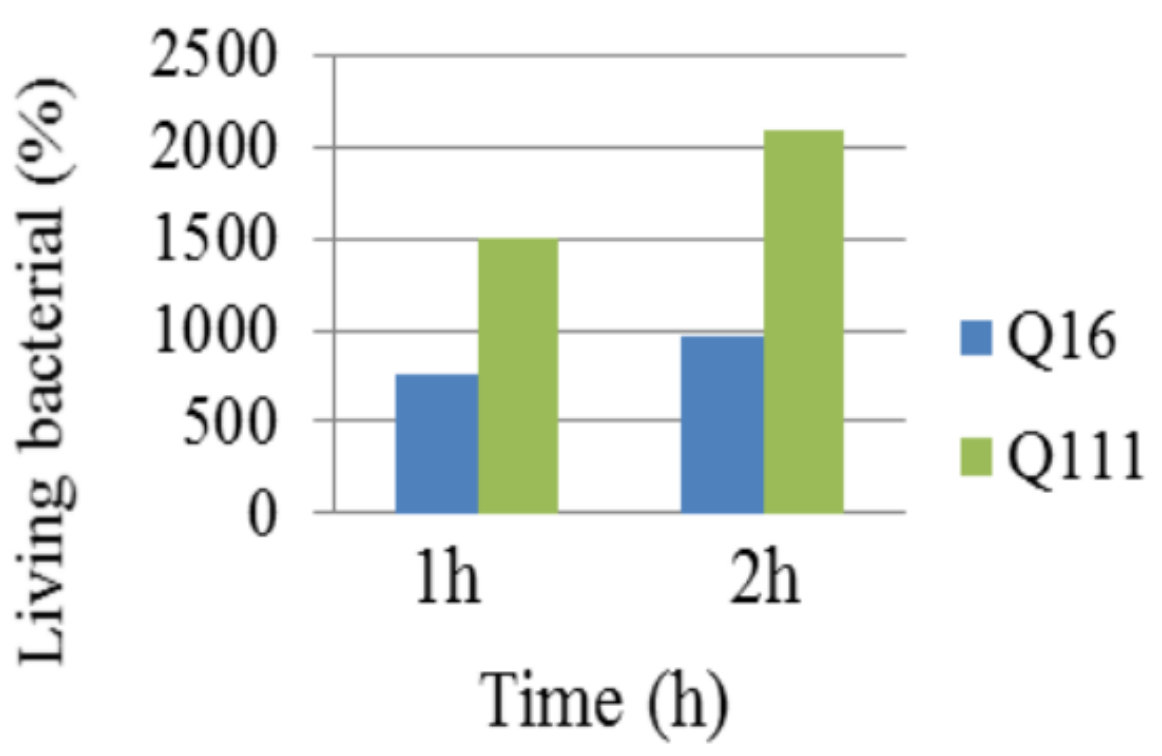

Figure 6. Living bacterial of strains test with $\mathrm{pH}=3$ 


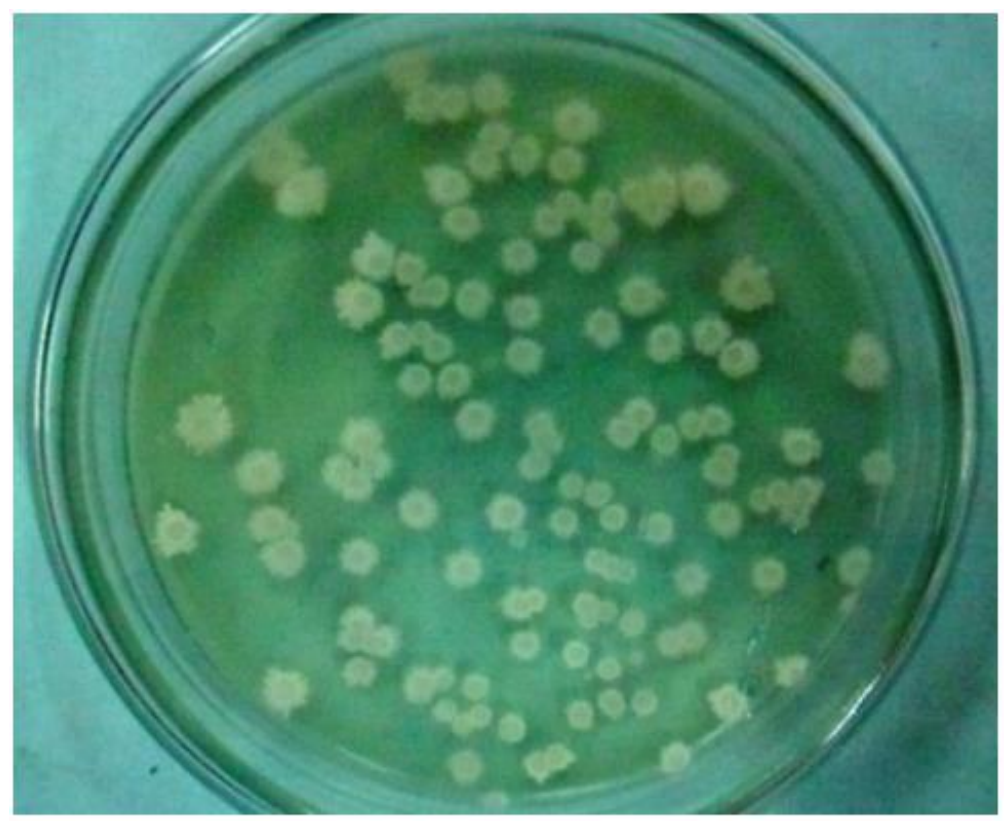

Figure 7. Acid gastric tolerance of Bacillus sp. Q16

\subsection{Resistance to bile salt test}

The result was shown in Figure 8, 9, 10.

The result showed Bacillus sp. $\mathrm{Q}_{16}$ could growth in bile salt $0,5 \%$ and the living rate was decreased extremely at $1 \%$ and $2 \%$. But Bacillus sp. $\mathrm{Q}_{111}$ could growth after $2 \mathrm{~h}$ at $0,5 \%$ and $1 \%$. In $2 \%$ concentration bile salt after $2 \mathrm{~h}$ culture, living rate of Bacillus sp. $\mathrm{Q}_{111}$ was more than Bacillus sp. Q16. In research of Sudha et al. (2010) showed Bacillus coagulans could live in media with $2 \%$ concentration bile salt.

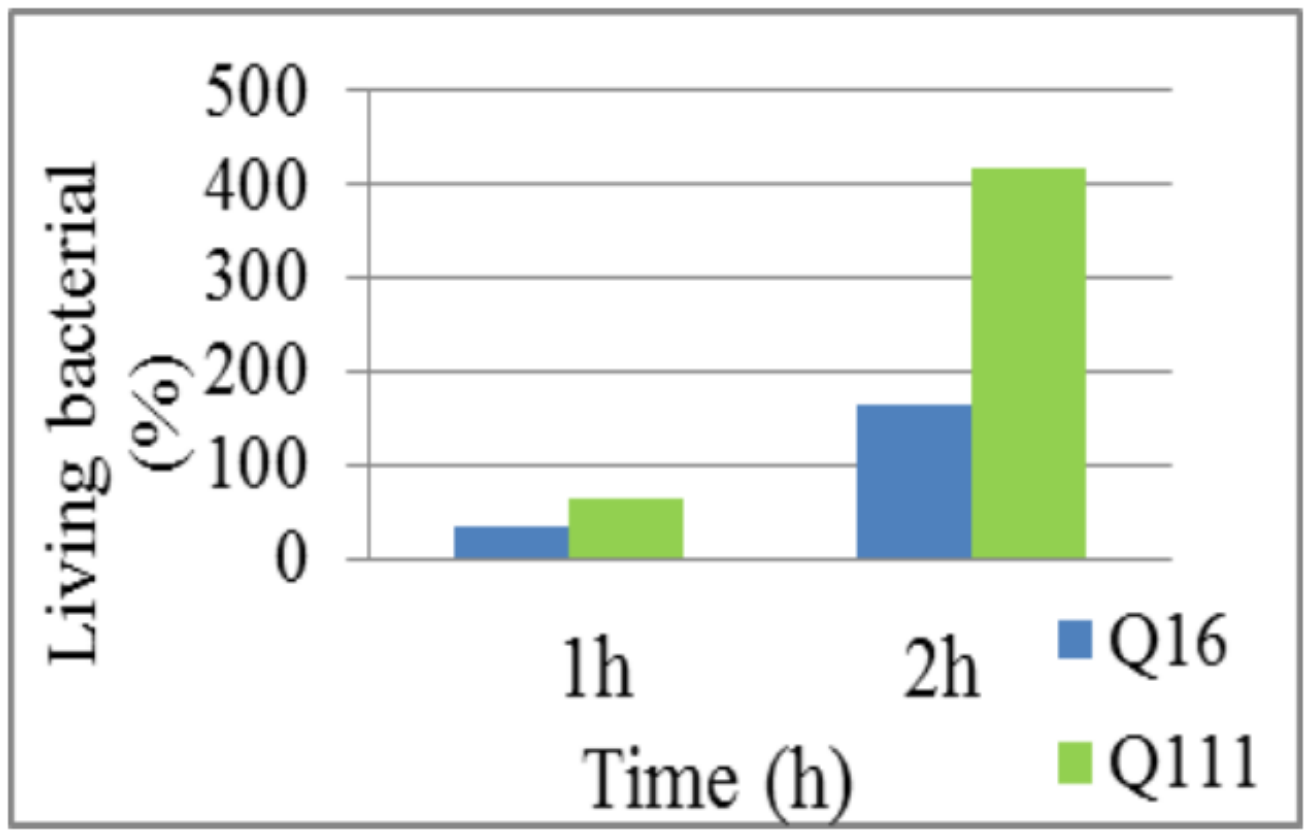

Figure 8. Living bacterial of strains test in bile salt $0,5 \%$ 


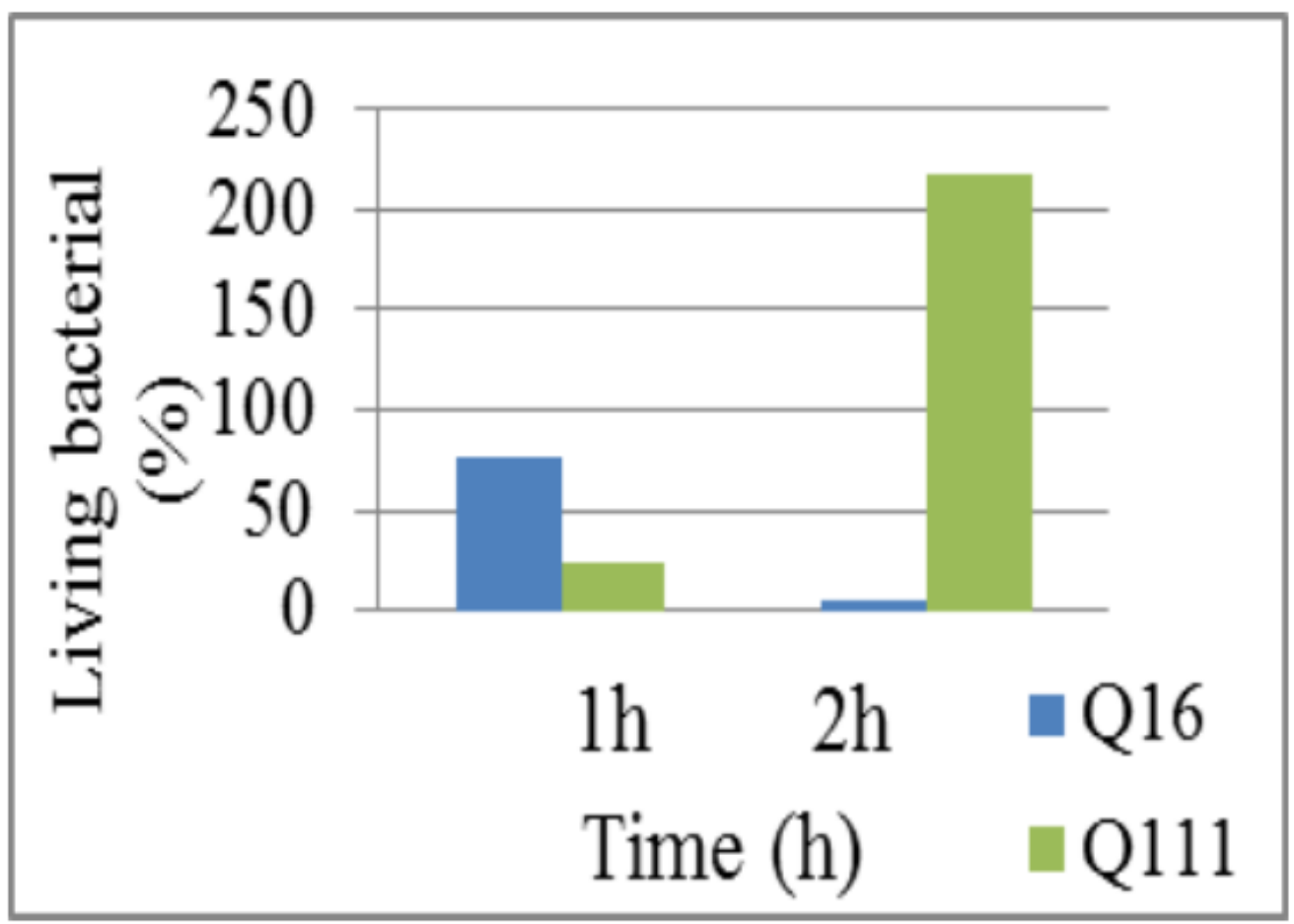

Figure 9. Living bacterial of strains test in bile salt $1 \%$

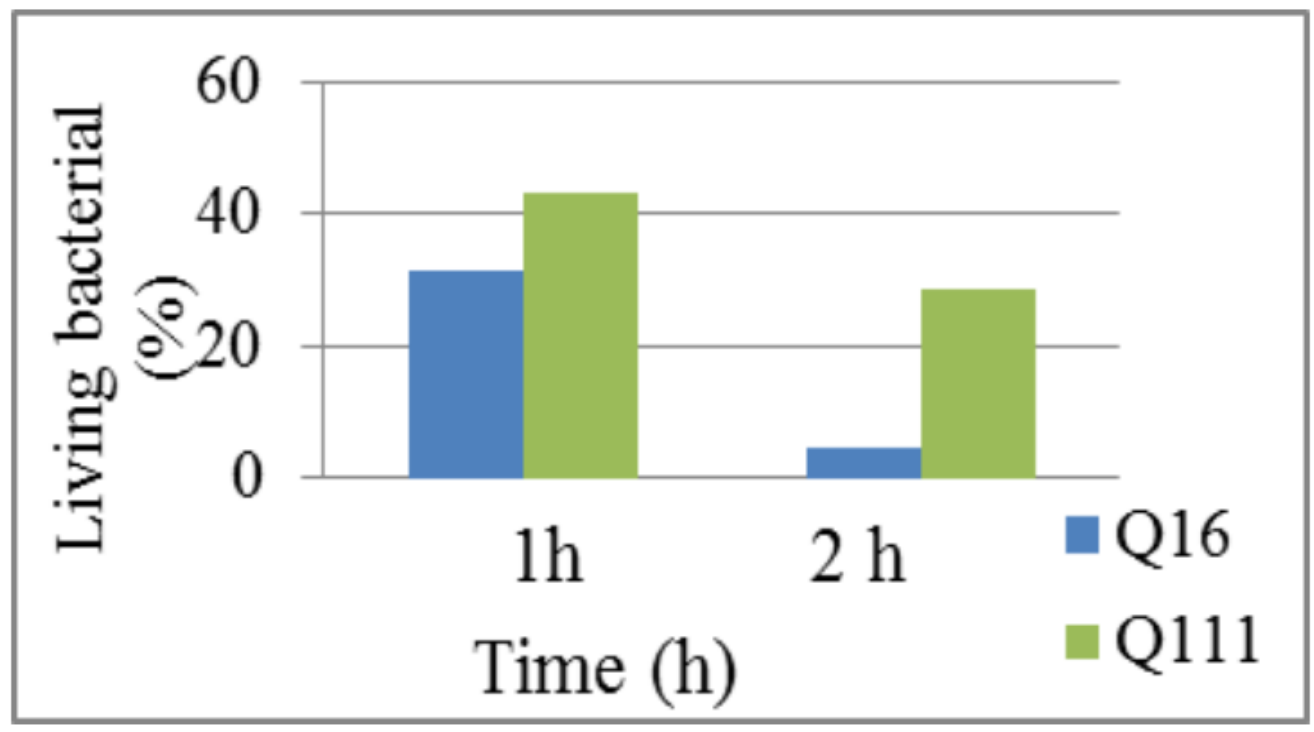

Figure 10. Living bacterial of strains test in bile salt $2 \%$ 


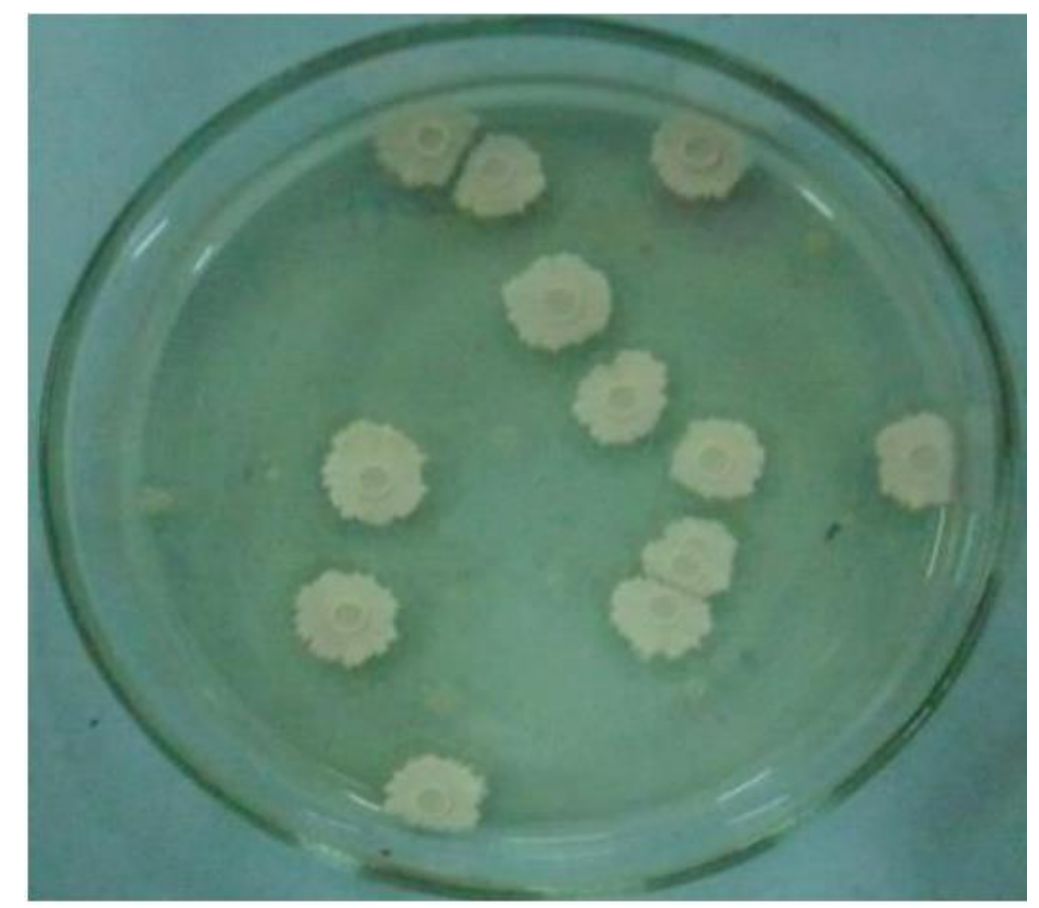

Figure 11. Bile salt tolerance of Bacillus sp. $\mathrm{Q}_{111}$ at 2\%

\subsection{Hemolysin test}

Bacillus sp. Q 16 và $\mathrm{Q}_{111}$ didn't have hemolysin $(\gamma)$ (Figure 12). This was the first step to recognize the characteristic disease, to apply safely to the human when it infected through food (Shafiqur, Shakila, Niamul, \& Manjurul, 2009).

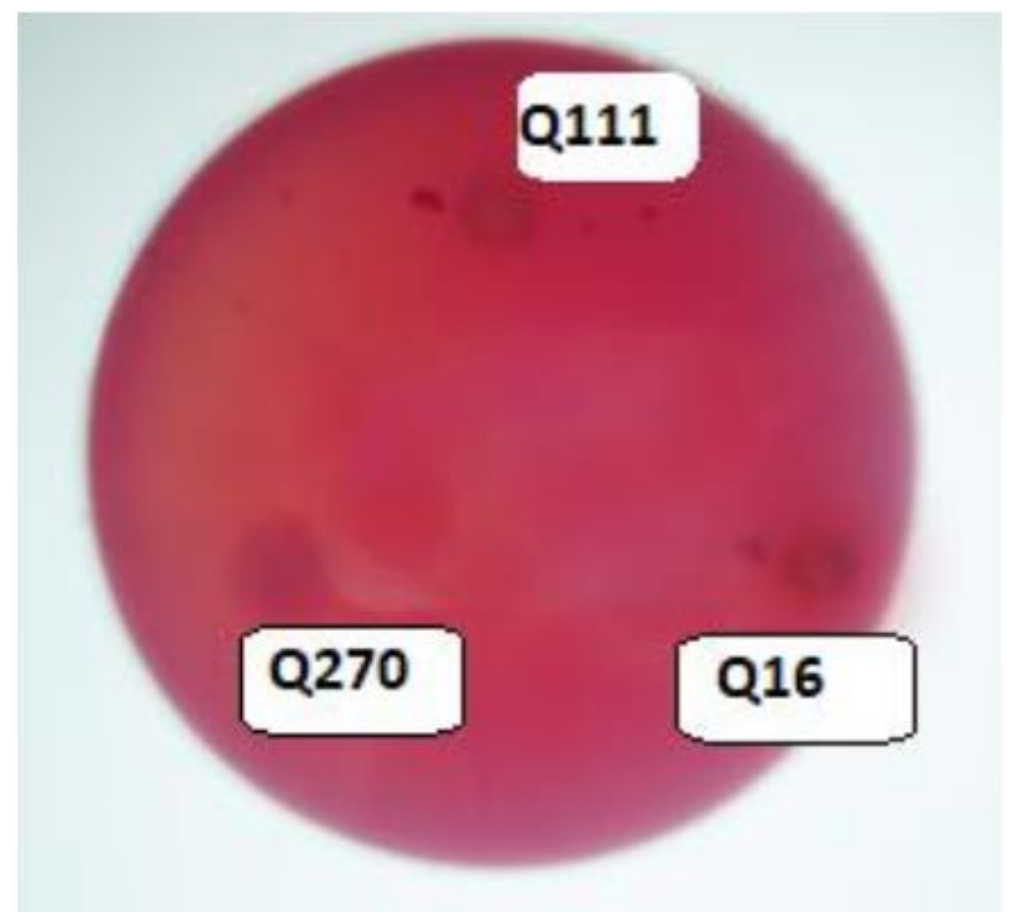

Figure 12. Hemolysin test of strains Bacillus sp. $Q_{16}$ và $Q_{111}$ 


\subsection{Sensitive antibiotic test}

Bacillus sp. $\mathrm{Q}_{111}$ and $\mathrm{Q}_{16}$ were sensitive to 8 antibiotics (penicillin, cefotaxime, vancomycin, chloramphenicol, erythromycin, gentamycin, tetracycline, ciprofloxacin) including in 3 impacting groups.

\subsection{Identification}

Based on Bergey (1994 as cited in Holt, Krieg, Sneath, Staley, \& Williams, 1994), Bacillus sp. Q 16 and $\mathrm{Q}_{111}$ were similar to Bacillus subtilis is $100 \%$ (20/20 test) by the biochemical method.

By molecular method based on sequence 16S rRNA, the sequence of 2 strains was compared to Genbank NCBI BLAST showed Bacillus sp. Q 16 and $\mathrm{Q}_{111}$ were similar $100 \%$ with Bacillus subtilis and Bacillus amyloliquefaciens. According to Kwon et al. (2009), sequence $16 \mathrm{~S}$ rRNA of B. subtilis and B. amyloliquefaciens couldn't distinguish. Therefore, we conducted 3 test biochemical $\alpha$-D-glucosidase production, CMC hydrolysis, L-tryptophanaminopeptidase production to distinguish B. subtilis and B. amyloliquefaciens (Cowan \& Steel, 1993). The test biochemical result of Bacillus sp. $\mathrm{Q}_{16}$ and $\mathrm{Q}_{111}$ showed that 2 strains similar to Bacillus subtilis (positive $\alpha$-D-glucosidase, positive CMC hydrolysis, negative L-tryptophanaminopeptidase). Based on the biochemical method and molecular method, Bacillus sp. Q16 and $\mathrm{Q}_{111}$ were identified as Bacillus subtilis.

We have to study some important experiments such as testing of evaluation about Bacillus safety, the ability of Bacillus strains to protect catfish against Edwardsiella ictaluri, optimization of the media of Bacillus strains to applicate for manufacturing the probiotics.

\section{Discussion}

Many studies show that Bacillus was used as a biological control in aquaculture. Bacillus strains isolated from soil or channel catfish intestine were screened for their antagonism against Edwardsiella ictaluri and Aeromonas hydrophila, the causative agents of enteric septicemia of catfish (ESC) and Motile Aeromonas Septicaemia (MAS). Many studies proved that the Bacillus spp. can secrete antibacterial compounds belonging to the peptide, lipopeptide, and bacteriocin (Abriouel, Franz, Omar, \& Gálvez, 2011). Aly, Ahmed, Ghareeb, and Mohamed (2008) showed that B. subtilis secretes antagonism to A. hydrophila and Pseudomonas fluorescens. Vo, Van, and Nguyen (2013) researched the probiotic products including a mixture of strains of B. circulans B3, B. subtilis N26.3, P. acidilactici LA61 used at a concentration of $1 \times 10^{7} \mathrm{CFU} / \mathrm{g}$ and catfish were fed in 4 weeks that could enhance the resistance and resist to purulent liver disease caused by E. ictaluri in catfish. According to Nguyen et al. (2013) selected two strains of Bacillus spp. $\left(\mathrm{Q}_{16}\right.$ and $\left.\mathrm{Q}_{111}\right)$ were the most resistant to E. ictaluri, and through the safety assessment and the protection ability test for pangasius under the infective condition with E. ictaluri showed that both strains Bacillus spp. ( $\mathrm{Q}_{16}$ and $\left.\mathrm{Q}_{111}\right)$ were safe and able to protect the host.

\section{Conclusion}

In this study, we selected 2 Bacillus spp. $\left(\mathrm{Q}_{16}\right.$ and $\left.\mathrm{Q}_{111}\right)$ that have potential probiotic, resistance to E. ictaluri. Additionally, there could produce 3 extracellular enzymes (amylase, protease, cellulase) which resist to saline, $\mathrm{pH}$, acid gastric, bile salt, that couldn't produce 
hemolysin enzyme resistance to the antibiotic. Therefore, this study results had the potential to make/produce probiotics, applications in aquaculture.

\section{ACKNOWLEDGMENTS}

This work was funded by Ho Chi Minh Open University.

\section{References}

Abriouel, H., Franz, C. M. A. P., Omar, N. B., \& Gálvez, A. (2011). Diversity and applications of Bacillus bacteriocins. FEMS Microbiology Reviews, 35(1), 201-232.

Aly, S. M., Ahmed, Y. A. G., Ghareeb, A. A. A., \& Mohamed, M. F. (2008). Studies on Bacillus subtilis and Lactobacillus acidophilus, as potential probiotics, on the immune response and resistance of Tilapia nilotica (Oreochromis niloticus) to challenge infections. Fish \& Shellfish Immunology, 25(1/2), 128-36. doi:10.1016/j.fsi.2008.03.013

Barrow, G., \& Feltham, R. (1993). Cowan and Steel's manual for the identification of medical bacteria. Cambridge, UK: Cambridge University Press.

Cha, J. H., Rahimnejad, S., Yang, S. Y., Kim, K. W., \& Lee, K. J. (2013). Evaluations of Bacillus spp. as dietary additives on growth performance, innate immunity and disease resistance of olive flounder (Paralichthys olivaceus) against Streptococcus iniae and as water additives. Aquaculture, 402-403, 50-57. doi:10.1016/j.aquaculture.2013.03.030

Chao, R., Abel, C., Malachi, A. W., Nancy, C., Bui, C. T. D., Joseph, C. N., .. Mark, R. L. (2012). Identification of Bacillus strains for biological control of catfish pathogens. PLOS One, 7(9), 1-9.

Cowan, S. T., \& Steel, K. J. (1993). Cowan and Steel's manual for identification of medical bacteria (3rd ed.) (pp. 199-241). Cambridge, UK: Cambridge University Press.

Cukrowska, B., Motyl, I., Kozáková, H., Schwarzer, M., Górecki, R. K., Klewicka, E., ... Libudzisz, Z. (2009). Probiotic Lactobacillus Strains: In vitro and in vivo Studies, Folia Microbiologica, 54(6), 533-537.

Dang, O. T. H., \& Nguyen, P. T. (2012). Trial of Edwardsiella ictaluri on Pangasius hypophthalmus by Erythromycin Thiocynate antibiotic. Can Tho University Journal of Science, 2012(22c), 146-154.

Hankin, L., \& Anagnostakis, S. L. (1975). The use of solid media for detection of enzyme production by fungi. Cryptogamie, Mycologie, 67(3), 597- 607.

Ho, T. T. T., Nguyen, H. T., Nguyen, N. T., Ong, M. Q., Korntip, K., Sasimamas, U., \& Nontawith, A. (2017). Identification and characterization of potential probiotic Bacillus spp. for application in striped catfish (Pangasianodon hypophthalmus [Sauvage, 1878]). Journal of Fisheries and Environment, 41(2), 20-32.

Holt, J. G., Krieg, N. R., Sneath, P. H. A., Staley, J. T., \& Williams S. T. (1994). Bergey's manual of determinative bacteriology (9th ed.). Philadelphia, PA: Lippincott Williams \& Wilkins.

Huynh, A. H., Le, H. D., \& Cutting, S. M. (2005). The use of bacterial spore formers as probiotics. FEMS Microbiol Reviews, 29(4), 813-835. doi:10.1016/j.femsre.2004.12.001 
Hyronimus, B., Marrec, C. L., Sassi, A. H., \& Deschamps, A. (2000). Acid and bile tolerance of spore-forming lactic acid bacteria. International Journal of Food Microbiology, 61(23), 193-197. doi:10.1016/s0168-1605(00)00366-4

Jock, S., Völksch, B., Mansvelt, L., \& Geider, K., (2002). Characterization of Bacillus strains from apple and pear trees in South Africa antagonistic to Erwinia amylovora. FEMS Microbiology Letters, 211(2), 247-252. doi:10.1111/j.1574-6968.2002.tb11232.x

Joo, M., Hur, S., Han, Y., \& Kim, J. (2007). Isolation, indentification and characterization of Bacillus strains from the traditional Korean soybean-fermented food, Chungkookjang. Journal of Applied Biological Chemistry, 50(4), 202-210.

Kwon, G. H., Lee, H. A., Park, J. Y., Kim, J. S., Park, C. S., Kwon, D. Y., ... Kim, J. H. (2009). Development of a RAPD-PCR method for identification of Bacillus species isolated from Cheonggukjang. International Journal of Food Microbiology, 129(3), 282-287. doi:10.1016/j.ijfoodmicro.2008.12.013

Lemos, M. L., Toranzo, A. E., \& Barja, J. L. (1985). Antibiotic activity of epiphytic bacteria isolated from intertidal seaweeds. Microbial Ecology, 11(2), 149-163. doi:10.1007/BF02010487

Ma, C. W., Cho, Y. S., \& Oh, K. H. (2009). Removal of pathogenic bacteria and nitrogens by Lactobacillus spp. JK-8 and JK-11. Aquaculture, 287(3/4), 266-270. doi:10.1016/j.aquaculture.2008.10.061

Montville, T. J. (1983). Dual-substrate plate diffusion assay for proteases. Applied and Environmental Microbiology, 45(1), 200-204.

Moriarty, D. J. W. (1997). The role of microorganisms in aquaculture ponds. Aquaculture, 151(1-4), 333-349.

Moriarty, D. J. W. (2006). Safety of aquaculture probiotics. Global Aquaculture Advocate, 8687.

Nguyen, M. V., Nguyen, D. H. T., Do, Q. P., Vo, N. N. Y., Duong, L. N., Nguyen, T. T. N., \& Le, P. H. (2013). Biocontrol of pathogenic Edwardsiella ictaluri by Bacillus spp. isolated from catfish pond. Journal of Science and Technology, 51(5C), 508-512.

Samanta, R., Pal, D., \& Sem, S. P. (1989). Production of hydrolases by N2 fixing microorganisms. Biochemie and Physiologie der pflanzen, 185(1/2), 75-81.

Sánchez-Ortiz, A. C., Luna-González, A., Campa-Córdova, A. I., Escamilla-Montes, R., Flores-Miranda, M. C., \& Mazon-Suastegui, J. M. (2015), Isolation and characterization of potential probiotic bacteria from pustulosebark (Anadara tuberculosa) suitable for shrimp farming. Latin American Journal of Aquatic Research, 43(1), 123-136.

Schwalbe, R., Steele, M. L., \& Goodwin, A. C. (2007). Antimicrobial susceptibility testing protocols. Boca Raton, FL: CRC Press.

Shafiqur, R., Shakila, N. K., Niamul, N. M., \& Manjurul, K. M. (2009). Application of probiotic bacteria: A novel approach towards ensuring food safety in shrimp aquaculture. Journal of Bangladesh Academy of Sciences, 33(1), 139-144. 
Sudha, M. R., Chauhan, P., Dixit, K., Babu, S., \& Jamil, K. (2010). Molecular typing and probiotic attributes of a new strain of Bacillus coagulans - Unique IS-2: A potential biotherapeutic agent. Genetic Engineering and Biotechnology Journal GEBJ, 7, 1-20.

Vo, M. S., Van, T. T., \& Nguyen, T. N. T. (2013). Dietary administration of the probiotic enhanced innate immune responses and disease resistance of the striped catfish against Edwardsiella ictaluri. Journal of Agriculture and Rural Development, 14, 81-89. 